\title{
Development and quality evaluation of bread supplemented with jackfruit seed flour
}

\author{
Mohammad Tafazzal Hossain ${ }^{1}$, Mohammad Mojaffor Hossain ${ }^{1}$, Manobendro Sarker ${ }^{1,}$, \\ Asadur Nur Shuvo², Mohammad Mahbubul Alam³, Mohammad Siddiqur Rahman ${ }^{4}$ \\ ${ }^{1}$ Department of Food Processing and Preservation, Hajee Mohammad Danesh Science and Technology University, Dinajpur, Bangladesh \\ ${ }^{2}$ Lab Incharge, Six Seasons Food \& Beverages Limited, Valuka, Bangladesh \\ ${ }^{3}$ School of Food Science and Technology, Jiangnan University, Wuxi, Jiangsu Province, China \\ ${ }^{4}$ Department of Agricultural and Industrial Engineering, Hajee Mohammad Danesh Science and Technology University, Dinajpur, \\ Bangladesh
}

\section{Email address:}

tafazzal.engg@gmail.com (M. T. Hossain), eng.mojaffor@gmail.com (M. M. Hossain), manob08@gmail.com (M. Sarker), shuvohstu@gmail.com (A. N. Shuvo), alammahbubu194@gmail.com (M. M. Alam),m_sq_rahman@yahoo.com (M. S. Rahman)

\section{To cite this article:}

Mohammad Tafazzal Hossain, Asadur Nur Shuvo, Mohammad Mahbubul Alam, Mohammad Mojaffor Hossain, Manobendro Sarker, Mohammad Siddiqur Rahman. Development and Quality Evaluation of Bread Supplemented with Jackfruit Seed Flour. International Journal of Nutrition and Food Sciences. Vol. 3, No. 5, 2014, pp. 484-487. doi: 10.11648/j.ijnfs.20140305.28

\begin{abstract}
The study was conducted to develop nutritionally enriched bread with the jackfruit seed flour supplementation to wheat flour. After washing and removing the outer brown layer, seeds were sliced and pretreated by blanching with $0.5 \%$ potassium metabisulphite for 10 minutes. The cabinet dehydration technique was applied for drying of jackfruit seeds at 60 ${ }^{0} \mathrm{C}$ for 24 hours and then dried slices were milled into jackfruit seed powder. The jackfruit seed flour was used in different proportion to find out the best composition for preparing bread with wheat flour. The percentages of jackfruit seed flour used in the breads were $25 \%, 35 \%, 45 \%$ and $55 \%$. After analyses, composite breads with different level of jackfruit seed powder were found nutritionally better than control sample. But a significant decrease in color, flavor, texture, taste and overall acceptability of breads was observed with the increase of substitution. Based on results, it can be concluded that bread with a substitution of $25 \%$ jackfruit seed flour was most acceptable in terms of nutritional value and overall acceptability compared to the control and other samples.
\end{abstract}

Keywords: Jackfruit Seed, Jackfruit Seed flour, Bread, Texture, Quality

\section{Introduction}

Jackfruit (Artocarpus heterophyllus Lam.) is the largest fruit among the edible fruits belongs to the family Moraceae (Goswami et al., 2010). It is originated in the forests of the Western Ghats (India). But now, it is largely grown in Bangladesh, Burma, India, Malaysia, Indonesia, Philippines, Thailand, Sri Lanka, and to some extent in Brazil and Australia. The poor people of jackfruit growing area in Bangladesh used to eat this fruit instead of rice for one of their daily meals. During summer season it is referred as "The Poor man's food" (Rahman et al., 1995). Nearly, 935965 tons of jackfruit come annually from an area of 9977 hectares at the rate of 93.81 tons per hectare (BBS, 2011). It ranks next to mango and banana in total but second in annual production among the fruits grown in
Bangladesh.

It is composed of rind, edible bulbs of yellow-flesh and seeds. The ripe fruits are eaten or processed into snacks and canned products. Seeds make up around 10 to $15 \%$ of the total fruit weight (30-365/fruit) and have high carbohydrate and protein contents (Ocloo et al., 2010). Mostly the seeds are discarded as waste, except sometimes they are boiled or roasted for consumption. As the seeds are recalcitrant and germinate immediately after maturity. Therefore, it is quite tough to store fresh seeds for long time. Due to the lack of processing and preservation techniques, huge amount of jackfruit seeds are destroyed every year in Bangladesh. As a result, a large amount of jackfruit seeds remain unused.

Normally, wheat flour in the confectionary and bakery industries is used as major ingredient. The price of wheat flour is increasing day by day. Jackfruit seed flour can be 
an alternative ingredient to be used in bakery and bread preparation in particular (Hasidah and Noor Aziah, 2003). However, jackfruit seed flour can be used with wheat flour to develop nutritious bakery products and such uses will reduce the postharvest loss of jackfruit seeds in Bangladesh. Based on the above information, the study was conducted to develop value added breads using jackfruit seed flour with wheat flour.

\section{Materials and Methods}

\subsection{Preparation of Jackfruit Seed Powder}

After collecting jackfruit seeds, the defected and germinated ones were sorted out. Then white aril and the brown spermoderm of seeds were and washed with distilled water. After cutting into slices by $2 \mathrm{~mm}$, slices were blanched at $70{ }^{0} \mathrm{C}$ with $0.5 \%$ KMS for 10 minutes. Pretreated slices were dried in cabinet dryer (Model- 13612, Seoul, Korea) at $60{ }^{0} \mathrm{C}$ for 24 hours followed by grinding into powder nearly $0.2 \mathrm{~mm}$ using a grinder (Japan CM/L- 7360065, Japan). The powder was sieved (MIC-212) and packed in high density polyethylene bags for further study.

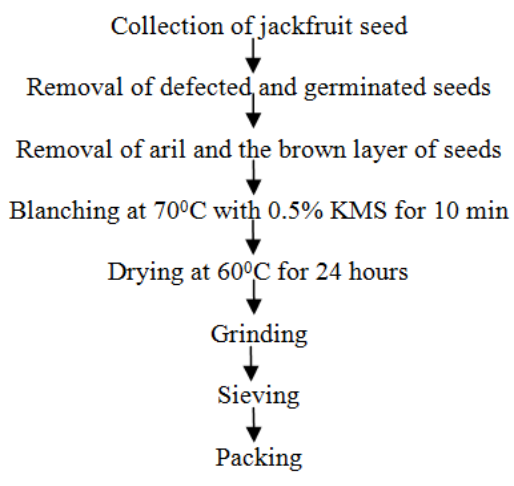

Figure 1. Preparation of jackfruit seed flour

\subsection{Chemical Analysis of Jackfruit Seed Flour}

Analyses were carried out to determine the moisture, crude protein, crude fat, crude fiber and total ash in accordance with the official methods of the Association of Official Analytical Chemist (AOAC, 2002).

\subsection{Bread Preparation}

The wheat flour was then mixed with varying inclusions of $0,25,35,45$ and $55 \%$ of the jackfruit seed flour. The composite flours were mixed with rest of baking ingredients (Table 1), and kneaded for 5 min into consistent dough and the resulting dough was molded and placed in a pre-oiled baking bowl. The dough was proofed for $40 \mathrm{~min}$ at $35{ }^{\circ} \mathrm{C}$ and then baked in oven for $35 \mathrm{~min}$ at $217{ }^{\circ} \mathrm{C}$ according to Ndife et al. (2011).

\subsection{Chemical Analysis of Bread}

Prepared bread was analyzed to determine the moisture, crude protein, crude fat, crude fiber, and total ash in accordance with the official methods of the Association of Official Analytical Chemist (AOAC, 2002).

\subsection{Sensory Analysis}

Sensory acceptability of prepared bread was evaluated by 30 panelists on a nine-point hedonic scale to evaluate sensory characteristics including odor, texture, taste and overall acceptability of breads. Where 9=like extremely, $8=$ like very much, $7=$ like moderately, $6=$ like slightly, 5= neither like or dislike, $4=$ dislike slightly, $3=$ dislike moderately, $2=$ dislike very much and $1=$ dislike extremely as described by Ndife et al. (2011).

\subsection{Statistical Analysis}

The data of proximate analyses and sensory evaluation of bread were statistically analyzed using MSTAT-C for windows version 2 and results were expressed as mean values standard deviation.

Table 1. Formulation of whole-wheat and composite breads

\begin{tabular}{llllll}
\hline Ingredients & Control & $\begin{array}{l}\text { Sample } \\
\text { A }\end{array}$ & $\begin{array}{l}\text { Sample } \\
\text { B }\end{array}$ & $\begin{array}{l}\text { Sample } \\
\text { C }\end{array}$ & $\begin{array}{l}\text { Sample } \\
\text { D }\end{array}$ \\
\hline Wheat Flour (g) & 100 & 75 & 65 & 55 & 35 \\
Jackfruit Seed Flour & 0 & 25 & 35 & 45 & 55 \\
(g) & & & & 3 & 3 \\
Dry Yeast (g) & 3 & 3 & 3 & 6 & 6 \\
Sugar (g) & 6 & 6 & 6 & 2 & 2 \\
Salt (g) & 2 & 2 & 2 & 3 & 3 \\
Shortening (g) & 3 & 3 & 3 & 0.2 & 0.2 \\
Emulsifier (GMS) (g) & 0.2 & 0.2 & 0.2 & 0.2 \\
Water (ml) & 55 & 55 & 55 & 55 & 55 \\
\hline
\end{tabular}

\section{Results and Discussion}

\subsection{Yield of Jackfruit Seed Flour}

After removal of white arils and the brown layer, weight of $100 \mathrm{~g}$ seed reduced to $95 \mathrm{~g}$. After drying, the slices were milled into flour and the weight of the flour recorded 48.25 g. This result was slightly higher than the result $(46 \%)$ reported by Chowdhury et al. (2012).

\subsection{Chemical Analysis of Seed Flour}

The moisture, carbohydrate, protein, fat, crude fiber and ash content of the prepared jackfruit seed flour were found $6.29 \%, \quad 73.37 \%, \quad 13.23 \%, \quad 1.30 \%, \quad 3.09 \%$ and $2.72 \%$ respectively. These results were similar with the results obtained by Ocloo et al. (2010) who found 6.09\% moisture, $79.34 \%$ carbohydrate, $13.50 \%$ protein, $1.27 \%$ fat, $3.19 \%$ crude fiber and $2.70 \%$ ash in jackfruit seed powder.

\subsection{Physico-Chemical Analysis of Bread Prepared with Jackfruit Seed Flour}

Nutrient contents in terms of moisture, protein, fat, ash, and carbohydrate of composite bread prepared with jackfruit seed flour at different proportion are shown in 
Table 2. The proximate values like moisture, protein, fat, ash and crude fiber content were lowest in whole wheat flour bread which served as control. But the proximate values of composite breads increased with increasing jackfruit seed flour substitution except fat and carbohydrate content.

Among composite breads, sample A scored lowest moisture content $32.25 \%$ whereas, the highest content moisture $39.87 \%$ was recorded in sample D. Moisture content of bread increased with the addition of jackfruit seed flour which was accordance with the result carried out by Siti Faridah and Noor Aziah (2012) who observed high amount of moisture in cake prepared with a higher substitution of jackfruit seed flour into wheat flour. Protein, crude fiber and ash content of bread increased with increasing of jackfruit seed flour in proportion of ingredients. Sample D scored highest value of protein $(11.35 \%)$, crude fiber $(4.09 \%)$ and ash $(2.10 \%)$, whereas protein $(9.1 \%)$, crude fiber $(2.10 \%)$ and ash $(1.64 \%)$ were recorded in sample A. These findings were in agreement with the findings of Siti Faridah and Noor Aziah (2012) who found higher protein, crude fiber and ash in cake prepared with higher substitution of jackfruit seed flour into wheat flour. But sample A contained highest carbohydrate $(51.86 \%)$ and fat $(3.05 \%)$ whereas, lowest carbohydrate $(40.90 \%)$ and fat $(1.69 \%)$ was recorded in sample D.

Physical characteristics of composite breads are shown in Table 3. The intensity of brown color and consistency of crust for both control sample and sample A was same. More brown color and poor texture of composite breads was found with more substitution of seed flour. Tough and browner crust was recorded for bread with 55\% substation (sample D).

Conversely, the crumb color of control sample and sample A were white brown, and the level of white color turned to brown with increasing the percentage of jackfruit seed flour. Deep brown color of crumb was found in sample D. Sample A was found with a perfect texture without any hardness and lumps along with silky surface. With the increase of jackfruit seed flour in proportion, hardness and poor texture of samples was observed, which was also found by Siti Faridah and Noor Aziah (2012).

Table 2. Proximate analysis of breads containing wheat flour and jackfruit seed flour (JSD).

\begin{tabular}{|c|c|c|c|c|c|c|c|}
\hline Sample & JSD (\%) & Moisture (\%) & Protein (\%) & Crude Fiber (\%) & Fat $(\%)$ & $\operatorname{Ash}(\%)$ & Carbohydrate (\%) \\
\hline Control & 0 & $28.50^{\mathrm{a}}$ & $8.25^{\mathrm{a}}$ & $2.0^{\mathrm{a}}$ & $3.35^{\mathrm{a}}$ & $1.5 \mathrm{a}$ & $56.4^{\mathrm{a}}$ \\
\hline A & 25 & $32.25^{\mathrm{ab}}$ & $9.10^{\mathrm{a}}$ & $2.1^{\mathrm{a}}$ & $3.05^{\mathrm{a}}$ & $1.64^{\mathrm{a}}$ & $51.86^{\mathrm{ab}}$ \\
\hline B & 35 & $35.15^{\mathrm{b}}$ & $9.55^{\mathrm{ab}}$ & $3.0^{\mathrm{b}}$ & $2.75^{\mathrm{b}}$ & $1.88^{\mathrm{ab}}$ & $47.67^{\mathrm{b}}$ \\
\hline $\mathrm{C}$ & 45 & $36.65^{\mathrm{bc}}$ & $9.69^{b}$ & $3.78^{\mathrm{c}}$ & $2.42^{\mathrm{bc}}$ & $1.92^{\mathrm{ab}}$ & $45.54^{\mathrm{c}}$ \\
\hline $\mathrm{D}$ & 55 & $39.87^{\mathrm{c}}$ & $11.35^{\mathrm{c}}$ & $4.09^{\mathrm{cd}}$ & $1.69^{c}$ & $2.10^{\mathrm{b}}$ & $40.90^{\mathrm{cd}}$ \\
\hline
\end{tabular}

Table 3. Physical characteristics of bread samples.

\begin{tabular}{|c|c|c|c|c|c|c|c|}
\hline \multirow{3}{*}{ Sample } & \multicolumn{2}{|c|}{ Crust Characteristics } & \multicolumn{5}{|c|}{ Crumb Characteristics } \\
\hline & \multirow{2}{*}{ Color } & \multirow{2}{*}{ Consistency } & \multirow{2}{*}{ Color } & \multicolumn{2}{|l|}{ Texture } & \multirow{2}{*}{ Odor } & \multirow{2}{*}{ Air Cell } \\
\hline & & & & Lumps and Hardness & Surface & & \\
\hline Control & Bright Brown & Tender & Bright Brown & Present Slightly & Smooth & Appetizing & Large \\
\hline A & Bright Brown & Tender & Bright Brown & Present Slightly & Smooth & Appetizing & Large \\
\hline B & Bright Brown & Slightly Tender & Bright Brown & Present Slightly & Smooth & Appetizing & Large \\
\hline $\mathrm{C}$ & Brownish & Medium Tough & Brownish & Present Slightly & Light Rough & Appetizing & Medium \\
\hline $\mathrm{D}$ & Brown & High Tough & Brown & Present & Light Rough & Sweet & Medium \\
\hline
\end{tabular}

\subsection{Sensory Evaluation}

Results of sensory evaluation of bread samples containing different amount of jackfruit seed flour as compared to the control are shown in Table 4. The score for color indicated that the color of control sample and sample A (10\% jackfruit seed flour substitution) were same. The color of composite breads changed from light-brown to darken with increasing seed flour.

The results shown in table 4 indicated that the flavors of different samples were not equally acceptable. Control sample and sample A both were most preferred, where ample D marked with lowest score (6.56) ( $\mathrm{p}>0.05)$.

There were significant differences $(p<0.05)$ in texture of control bread and composite breads were not like control sample. Among composite breads, sample A (25\% substitution) was the most preferred with a score 7.15 , whereas lowest score 5.97 was recorded for sample D (55\% substitution).

Table 4. Mean sensory score of bread samples

\begin{tabular}{llllll}
\hline \multirow{2}{*}{ Sensory Attributes } & Bread Type & & & & \\
\cline { 2 - 6 } & Control & Sample A & Sample B & Sample C & Sample D \\
\hline Color & $7.62^{\mathrm{a}}$ & $7.59^{\mathrm{a}}$ & $7.31^{\mathrm{a}}$ & $7.24^{\mathrm{a}}$ & $6.66^{\mathrm{b}}$ \\
Flavor & $7.45^{\mathrm{a}}$ & $7.42^{\mathrm{a}}$ & $7.10^{\mathrm{ab}}$ & $6.79^{\mathrm{bc}}$ & $6.56^{\mathrm{c}}$ \\
Texture & $7.23^{\mathrm{a}}$ & $7.15^{\mathrm{ab}}$ & $6.93^{\mathrm{b}}$ & $6.41^{\mathrm{ab}}$ & $5.97^{\mathrm{c}}$ \\
Taste & $7.17^{\mathrm{a}}$ & $7.14^{\mathrm{a}}$ & $6.73^{\mathrm{b}}$ & $6.43^{\mathrm{bc}}$ & $6.40^{\mathrm{bc}}$ \\
Overall acceptability & $7.69^{\mathrm{a}}$ & $7.65^{\mathrm{a}}$ & $7.05^{\mathrm{ab}}$ & $6.92^{\mathrm{b}}$ & $6.03^{\mathrm{c}}$ \\
\hline
\end{tabular}


There was no significant difference $(\mathrm{p}>0.05)$ in taste of control sample and sample A, where 7.17 and 7.14 was recorded for control sample and sample A respectively. Results showed significant differences $(p<0.05)$ in taste of breads with more substitution of jackfruit seed flour.

On overall acceptability, there is no significant difference ( $p>0.05$ ) between control sample and sample A and marked with score 7.69 and 7.65 respectively, whereas sample D scored lowest score (6.03) among the prepared samples.

The sensory evaluation revealed that sample A (wheat flour : jackfruit seed flour $=75: 25$ ) was only acceptable like control sample. This finding was very compatible with the findings of Siti Faridah and Noor Aziah (2012) who observed cake with jackfruit seed flour (20-25\% replacement of wheat flour) was best on overall acceptability.

\section{Conclusion}

This study results that jackfruit seed flour supplementation with wheat flour has a great potential in developing bakery products in spite of affecting sensory qualities. The addition of $25 \%$ jackfruit seed flour resulted in bread with a good overall acceptability, and it was nutritionally superior for higher carbohydrate, fat, protein, and crude fiber content to whole wheat bread. Based on nutritional facts and overall acceptability it can be concluded that it is feasible to produce nutritionally value added bread from jackfruit seed flour supplementation to wheat flour.

\section{References}

[1] AOAC. 2002. Official Methods of Analysis of the Association of Official Analytical Chemists, 16th Edition. Edited by Patricia Cunniff, Virginia, USA.

[2] BBS. 2011. Yearbook of Agricultural Statistics of Bangladesh. Planning Division, Ministry of Planning, Peoples Republic of Bangladesh, Dhaka.
[3] Chowdhury A.R.; Bhattacharyya A.K. and Chattopadhyay P. 2012. Study on functional properties of raw and blended jackfruit seed flour (a non-conventional source) for food application. Indian Journal of Natural Products and Resources. Vol. 3 (3), pp. 347-353.

[4] Goswami, C; Hossain, M.A.; Mortuzaand, M.G. and Islam. R. 2010. Physicochemical Parameters of Jackfruit (Artocarpus Heterophyllus Lam) Seeds in Different Growing Areas. Int. J. BioRes. 2 (10), pp. 01-05.

[5] Hasidah, M. Y. and Noor Aziah, A. A. 2003. Organoleptic and physico-chemical evaluation of breads supplemented with jackfruit seed (Artocarpus heterophyllus) flour. Proceeding Malaysian Science and Technology Congree (MSTC). Kuala Lumpur, Malaysia.

[6] Ihekoronye AI, Ngoddy PO (1985). Integrated Food Science and Technology for the Tropics. 2nd ed. Macmillan Publishers Ltd. London.

[7] Ndife, J.; Abdulraheem, L. O. and Zakari U. M. 2011. Evaluation of the nutritional and sensory quality of functional breads produced from whole wheat and soya bean flour blends. African Journal of Food Science Vol. 5(8), pp. $466-472$.

[8] Ocloo, F.C.K.; Bansa, D; Boatin, R; Adom, T and Agbemavor, W.S. 2010. Physico-chemical, functional and pasting characteristics of flour produced from Jackfruits (Artocarpus heterophyllus) seeds. Agriculture and Biology Journal of North America, 1(5), pp. 903-908.

[9] Rahman, A. K. M. M., Huq, E., Mian, A. J. and A. Chesson.1995. Microscopic and chemical changes occurring during the ripening of two forms jackfruit (Artocarpus heterophyllus L). Food Chemistry, 52: 405-410.

[10] Siti Faridah, M. A. and Noor Aziah, A. A. 2012. Development of reduced calorie chocolate cake with jackfruit seed (Artocarpus heterophyllus Lam.) flour and polydextrose using response surface methodology (RSM). International Food Research Journal 19(2), pp. 515-519.

[11] See, E.F.; Wan Nadiah, W.A. and Noor Aziah, A.A. 2007. Physico-Chemical and Sensory Evaluation of Breads Supplemented with Pumpkin Flour. ASEAN Food Journal 14 (2), pp. 123-130. 